\title{
ABANDONED AND FORGOTTEN? VIOLENT DEATHS OF PREVIOUSLY ABUSED FEMALE VICTIMS IN CROATIA***
}

Summary: $\quad$ The paper is divided into two parts to facilitate a clearer understanding of different aspects of the violent death of previously abused female victims.

The first part offers a brief overview of the most recent phenomenological conclusions on violence ending in death and explains the need to focus on gender differences in homicide victimisation. A bulk of research has confirmed that most women are more vulnerable to homicide within home and that the lethal outcome is an escalation of previously experienced abuse. In order to contribute to a more in-depth study of female intimate homicides, the authors focus on a variety of definitions and draw a clear line between the term femicide and the aggravated murder of a closely related person.

In the second part of the paper, the authors have analysed the case-law of the Supreme Court of the Republic of Croatia in which the perpetrators were found guilty of the criminal offence of aggravated murder of a closely related person (Art. 111, Para. 3 of the Criminal Code) in the period from 1 January 2013 to 1 June 2020. The research primarily focused on the circumstance of previous abuse, especially on the relationship between the victim and the perpetrator, the duration and frequency of abuse, and the reaction of the environment and competent authorities in cases where they knew about the abuse or when it was reported.

Keywords: femicide, aggravated murder, previous abuse, closely related person, domestic violence, case law

\footnotetext{
* Dalida Rittossa, PhD, Associate Professor, Faculty of Law, University of Rijeka, Hahlić 6, 51000 Rijeka, Republic of Croatia. E-mail address: dalida.rittossa@pravri.uniri.hr. ORCID: https://orcid.org/0000-0002-1452-0838.

** Marissabell Škorić, PhD, Full Professor, Faculty of Law, University of Rijeka, Hahlić 6, 51000 Rijeka, Republic of Croatia. E-mail address: skoric@pravri.hr. ORCID: https://orcid.org/0000-0003-0627-3651.

** This work has been supported in part by Croatian Science Foundation under the project IP-CORONA-04-2086.
} 


\section{INTRODUCTORY REMARQUES - WHY DO WE HAVE TO FOCUS ON GENDER DIFFERENCES IN HOMICIDE?}

Violence, in its different forms and manifestations, has been a constant, loyal companion of humanity. Recent scholarship in history and the social science has revealed that paradoxically, societies were experiencing a historical social change due to the systematic use of violence and mechanisms to limit and supress it. Throughout the years, the social development strategy was underpinned with the structural use of violence and reaction measures towards prohibited violence inflictors. As stated by current scholarly works, the continuum of violence is a central problem for any group and no society has ever solved this problem by eliminating violence, but rather developed different tactics, concepts and policies to contain it and manage it. ${ }^{1}$ Although it would be highly illusory to claim that violence can be annihilated, for centuries, the congruence of criminal law with community morality has been a legitimate means of diminishing group and individual violent incidents deemed as harmful, destructive and lastly, illegal. According to a number of phenomenological studies, violence ending with death, as in its most lethal form, is falling nearly everywhere. Cross-national studies confirm that crime rates for intentional homicide have decreased over time, and that the negative trend presents a sort of worldwide continuum for a quarter of a century. ${ }^{2}$ Last year, the United Nations Office on Drugs and Crime reported that the overall risk of suffering a violent death as a result of intentional homicide has been associated with a solid negative trend. In 2017, a homicide rate was estimated at 6.1 victims per 100,000 population while the number of victims in 1993 was 7,4 per 100,000. ${ }^{3}$ Alongside with the global phenomenological picture, homicide patterns and trends have a negative connotation in the United States and other Western countries. Dillbeck and Cavanaugh have shown that a decline in the United States in homicide is clear for several decades and that the noted decrease is supported by different official data. ${ }^{4}$ Tonry's in depth analysis confirms that in last couple of decades rates have fallen precipitately for homicide in western Europe. ${ }^{5}$

Numbers confirming significant lethal violence drop could be a valid predictor of efficient state policies to reduce the violent crime and the fact that criminal and moral norms combined together do have a deterring effect. Nevertheless, behavioural and social scientists warn us that accepting this thesis leads to a simplified perspective on the violent crime dynamic and criminological factors that potentiate its shifts in changing. The analysis has shown that most of the studies that measure overall homicide rates are gender-blind offer-

1 Douglass C North, John Joseph Wallis and Barry R Weingast, Violence and Social Orders: A Conceptual Framework for Interpreting Recorded Human History (rep edn, Cambridge University Press 2012) 13.

2 Maximilian Rudolph and Peter Starke, 'How does the welfare state reduce crime? The effect of program characteristics and decommodification across 18 OECD-countries' (2020) 68 Journal of Criminal Justice 101684 <https://doi.org/10.1016/j. jcrimjus.2020.101684> accessed 4 October 2021.

3 United Nations Office on Drugs and Crime, Global Study on Homicide 2019: Executive summary (United Nations 2019) 11 <https:// www.unodc.org/documents/data-and-analysis/gsh/Booklet1.pdf> accessed 4 October 2021.

4 Michael C Dillbeck and Kenneth L Cavanaugh, 'Societal Violence and Collective Consciousness: Reduction of U.S. Homicide and Urban Violent Crime Rates' (2016) 6(2) SAGE Open 1 <https://doi.org/10.1177/2158244016637891> accessed 4 October 2021. 
ing no say on gender differences in offending and victimisation. ${ }^{6}$ Researchers predominantly agree that men are more exposed to lethal violence than women and that homicide perpetration and serious violent behaviour toward others is mostly "a man thing". ${ }^{7}$ However, generalised conclusions as stated here remain tentative due to the lack of particular information about similarities and divergences in homicide fluctuation for male and female victims. Without more specific insight into females and males accounting for the differences in homicide incidence, it is highly improbable to comprehend multiple, individual and societal forces that affect crime rates. Focusing on gender differences in homicide victimisation is a necessary step towards better understanding of lethal violence occurrences that has to be taken in order to expend our scientific knowledge on gendered forms of violence and incorporate it in comprehensive policy actions. Widening the analytical lens to include a gender perspective, therefore, is important in both theoretical and policy domains. For example, the research on gender differences in homicide is worthy of scholarly attention bearing in mind that it is a reliable predictor of the level of gender equality in a certain community. According to True, societies with more gender equal structures are overall less violent, ${ }^{8}$ and more gender equality and less violence is a corresponding target under the UN Sustainable Development Goals. ${ }^{9}$ In order to reach peaceful and inclusive society by 2030, humanity has to act quickly, decisively and strategically to achieve empowerment and social, economic and political inclusion of all, irrespectively of their sex, and to attain significant reduction of all forms of violence and related death rates.

The next decade call is particularly noteworthy knowing that 87000 women and girls were victims of intentional homicide in $2017 .{ }^{10}$ Thought the world, women are subjected to lethal violence, a pervasive and widespread continuum that targets them all regardless of their age, race, ethnicity, national origin, religion, socio-economic or marital status and other personal characteristics. Studies have demonstrated that one woman is killed by a man every 2.5 days in the United Kingdom ${ }^{11}$ and two women every 3 days in Italy. ${ }^{12}$ Even if official data show that female homicide victimisation is declining in most European countries, the analysis reveals that the noted negative trend is not as sharp nor as clear as for male victimisation. ${ }^{13}$ Women are at more constant risk for homicide than men in every society in the world, however, certain women are more vulnerable to acts of intentional deprivation of life. Frequently reached research conclusions unrelentingly point at a strong casual relation between intimate and domestic violence and female homicide. As to Kennedy's findings, one woman is deprived of her life every week in a domestic situation in the United Kingdom, ${ }^{14}$ and the numbers are

6 Rossella Selmini and Suzy McElrath, 'Violent Female Victimization Trends across Europe, Canada, and the United States' (2014) 43 Crime and Justice 368.

7 Maggie Wykes and Kirsty Welsh, Violence, Gender and Justice (Sage Publications 2009) 38.

8 Jacqui True, 'Continuums of Violence and Peace: A Feminist Perspective' (2020) 34(1) Ethics \& International Affairs 85.

9 United Nations General Assembly, Transforming our world: the 2030 Agenda for Sustainable Development (Resolution A/RES/70/1, 25 September 2015).

UNODC (n 3) 14.

11 Heather Savigny, Cultural Sexism: The Politics of Feminist Rage in the \#metoo Era (Bristol University Press 2020) 51-52.

12 Alessandra Calanchi, 'Crime, Crime Fiction, and the Construction of Public Feeling through the Media in Italy' (2014) 32(2) Italian Americana 173.

13 Selmini (n 6) 387. 
almost similar in other parts of the world. A routinised violence in intimate and family settings against women was detected in South Africa where at least one woman dies every 6 days at the hands of her male partner. ${ }^{15}$ Each year former or current intimate partners in Canada commit homicide against a female intimate in around 60 cases. ${ }^{16}$ Loinaz and colleagues point at similar data concluding that 65 women are killed by their husbands or male companions annually in Spain over the last decade. ${ }^{17}$ A detailed analysis of data for 66 countries has revealed that prevalence of intimate partner homicides among all female homicides is $38.6 \% .^{18}$ According to Manjoo, numbers are more alarming and call for an immediate intervention due to the fact that $40 \%$ to $70 \%$ of female homicide victims die as a result of intimate male violence. ${ }^{19}$ Rooted in multiple endogenous and exogenous causes, and strongly linked to cultural and societal tolerance towards intimate and domestic violence, in only five years (from 2012 to 2017) the share of women killed by their family member globally rose from $47 \%$ of all female homicide victims to $58 \% .^{20}$

Except from the fact that women continue to bear the heaviest burden of lethal victimization within home, research suggests that in most cases a death of a woman is not an individual violent incident, rather the fatal outcome of series of previously experienced violent events. ${ }^{21}$ Female homicide in the context of intimate / domestic violence is its most severe manifestation, the ultimate act in the range of previously experienced abuse. In fact, findings suggest that the final, violent moments of woman's life more likely present the climax of sustained and escalating violence in private settings while the non-intimate acts of killing are more likely individual incidents driven by antisocial or predatory motives. ${ }^{22}$ The continuum of violence resulting with death in the abusive relationship bears unique characteristics. A bulk of research has confirmed that repeated abuse is a precipitating factor in intimate homicide perpetuated by both men and women, however, a more prevailing motive that pushes women to kill their partners is to stop partner's abuse, act out of fear and defend themselves and their children while men are more driven by jealousy, possessiveness, revelations of partner's infidelity or imminent or actual termination of a relationship. ${ }^{23}$ The complexity

15 Pamela Shifman, Nozizwe Madlala-Routledge and Viv Smith, 'Women in Parliament Caucus for Action to End Violence' (1997) 13(36) Agenda: Empowering Women for Gender Equity 25.

16 Isabel Grant, 'Intimate Famicide: A Study of Sentencing Trends for Men Who Kill Their Intimate Partner's' (2010) 47(3) Alberta Law Review 780.

17 Ismael Loinaz, Isabel Marzabal and Antonio Andrés-Pueyo, 'Risk Factors of Female Intimate Partner and Non-Intimate Partner Homicides' (2018) 10(2) The European Journal of Psychology Applied to Legal Context 49.

18 Heidi Stöckl and others, 'The Global Prevalence of Intimate Partner Homicide: A Systematic Review' (2013) 382(9895) The Lancet 862.

19 Rashida Manjoo, 'The Continuum of Violence against Women and the Challenges of Effective Redress' (2012) 1(1) International Human Rights Law Review 13.

$20 \operatorname{UNODC}$ (n 3) 14

21 Grant (n 16) 781; Jane Koziol-McLain and others, 'Risk Factors for Femicide-Suicide in Abusive Relationships: Results form a Multisite Case Control Study' (2006) 21(1) Violence and Victims 6; Judith McFarlane, Jacquelyn C Campbell and Kathy Watson, 'The Use of the Justice System Prior to Intimate Partner Femicide' (2001) 26(2) Criminal Justice Review 205.

22 Georgia Zara and others, 'The Medicolegal, Psycho-Criminological, and Epidemiological Reality of Intimate Partner and NonIntimate Partner Femicide in North-West Italy: Looking Backwards to See Forwards' (2019) 133(4) International Journal of Legal Medicine 1295.

23 Caroline Dick, 'A Tale of Two Cultures: Intimate Femicide, Cultural Defences, and the Law of Provocation' (2011) 23(2) Canadian Journal of Women and the Law 525; Daniel G Saunders and Angela Browne, 'Intimate Partner Homicide' in RT Ammerman and M Hersen (eds), Case Studies in Family Violence (Kluwer Academic Publishers 2000) 419-21. More recent research has 
of motives, relations, causes and violence continuum in intimate female homicides has been in focus of research interest in the past years, and relevant research conclusions were used as a solid basis for different forms of political activism at national and international level. Nowadays, a widely accepted consensus exists that female homicide is a human rights issue that has to be addressed by state actors, international organisations, civil society, women's groups and networks and by researchers as well. ${ }^{24}$ This article is a direct contribution toward a more in-depth study of this theme.

\section{FEMICIDE V. AGGRAVATED MURDER - LEGISLATIVE SUBTLETIES AND THE POLITICAL NARRATIVE IN WOMEN'S HUMAN RIGHTS DISCOURSE}

\subsection{FEMICIDE - ALL THE SHADES OF SCIENTIFIC DEFINITIONS}

Almost two decades ago, Stout rightly concluded that the first step in any research or practice endeavour is to identify the problem..$^{25}$ Undoubtedly, female intentional homicide has been identified as a pressing social issue deserving lay public and scientific attention. Professionals from different fields have concluded that this issue is worth pursuing in research and offered a variety of definitions and descriptions of the phenomenon, each focussing on different manifestations or components of criminal incident. Due to noted scientific creativity and differentiation embodied in defining, terminology used in scholarly literature is considerably varied. The most commonly used synonym for female homicide in theoretical and professional literature is found to be the term femicide although the consensus about its etymology is missing. Zara and colleagues believe that the term femicide was first coined by Corry in $1801,{ }^{26}$ an Irish journalist who was an ardent critic of London urban culture and questionable morality of Londoners. In a series of brisk tales for his "A Satirical View of London", Corry uses the term femicide to describe seducing of young girls by married men with the consequence of losing their virtue because "female chastity is a true foundation of national honour" and "the monster who betrays a credulous virgin, and consigns her to infamy, is in reality a most relentless murderer!"27 Interesting, too, is the fact that Parmigiani likewise traces the origins of the word femicide back to the $19^{\text {th }}$ century, the time when "femminicidio", the Italian translation of the word in question, was mentioned timidly in Italian literature. ${ }^{28}$ On the other hand, according to Douglas, the word femicide indeed originated in the beginning of the $19^{\text {th }}$ century, however, the written source which should be cited following the etymological analysis is Wharton's Law Lexicon pub-

documented that motivational precursors like jealousy, retaliation and self-defense can be found in both female and male perpetrators. Jennifer Langhinrichsen-Rohling, Adrianne McCullars and Tiffany A Misra, 'Motivations for Men and Women's Intimate Partner Violence Perpetration: A Comprehensive Review' (2012) 3(4) Partner Abuse 441.

In-depth study on all forms of violence against women: Report of the Secretary-General (United Nations General Assembly, Document A/61/122/Add.1, 6 July 2006) 9. 
lished in $1848 .{ }^{29}$ Wharton's definition conveyed more precise meaning with stronger reference to legal substance of homicide. Forged under the principle that legal definitions should be as simple and coherent as possible, it was focused on deprivation of life as an action and on a single victim's characteristics, i.e. victim's sex. For Wharton, the term femicide referred to the killing of a woman..$^{30}$ The semantic interpretation of a femicide as a legal term was carried out in the spirit of $19^{\text {th }}$ century lexical defining which sought to explain the meaning of a word at specific historical moment and at that time, historical claims were created without gender context. For example, similar lexical definitions can be found for the term infanticide as the killing of a child after it is born or for matricide as the slaughter of a mother. ${ }^{31}$ Over the years, Wharton's definition was almost forgotten and even though the term femicide was not much used, after more than a century, it re-emerged in public discourses and research discussions on female homicide. In 1998, Cambell and Runyan used the term femicide to refer to the homicide of women. According to them, femicide is defined as all killings of women, regardless of motive or perpetrator status. ${ }^{32}$ In reviewing the literature, it becomes apparent that this was just a starting point in defining femicide. While different theoretical layers have been added to our understanding of femicide, the term itself continues to evolve in meaning.

Nowadays, a significant number of authors that study lethal male-on-female violence define femicide as an act of killing a woman because she is a woman. ${ }^{33}$ The term femicide can be understood as the corollary to homicide, ${ }^{34}$ or rather conceptualisation of a new category of homicide defined by gender conflict. ${ }^{35}$ The proposed definition consists of four crucial elements: the illegal action, deprivation of life as its outcome, victim's status and offender's motives. Most researchers employ a broader definition of femicide adding another crucial element, the sex of the offender, transforming the femicide into males killing females because they are females. ${ }^{36}$ The noted theoretical tactics promote incorporation of feminist perspective on violence against women that ascribes a structural explanation based on gender asymmetry in power relationships and male control over women. Gender-related crimes present a manifestation of an unequal division of power between men and women in society and at the same time perpetuate further inequalities. ${ }^{37}$ Violence and force have consistently manifested itself as a case and a cause of maintaining the gender hierarchy and bearing this in mind,

29 Aarol Anne Douglas, 'Femicide in Global Perspective' (2001) 31(11) Off Our Backs 31.

30 John Jane Smith Wharton, The Law Lexicon or Dictionary of Jurisprudence: Explaining All the Technical Words and Phrases Employed in the Several Departments of English Law; Including Also the Various Legal Terms Used in Commercial Transactions; Together with an Explanatory as Well as Literal Translation of the Latin Maxims Contained in the Writings of the Ancient and Modern Commentators (Spettigue and Farrance 1848) 251.

31 John Jane Smith Wharton and John Mounteney Lely, Wharton's Law-Lexicon: Forming an Epitome of the Law of England; And Containing Full Explanations of the Technical Terms and Phrases Thereof, Both Ancient and Modern. Including the Various Legal Terms Used in Commercial Business; Together with a Translation of Latin Law Maxims, and Selected Titles from the Civil, Scotch, and Indian Law (7th edn, Soule and Bugbee 1883) 408, 517.

32 Jacquelyn Campbell and Carol Runyan, 'Femicide: Guest Editors Introduction' (1998) 2(4) Homicide Studies 347-52.

33 Diana EH Russell and Roberta A Harmes, Femicide in Global Perspective (Teachers College Press 2001) 3.

34 Hilda Morales Trujillo, 'Femicide and Sexual Violence in Guatemala' in RL Fregoso and AC Bejarano (eds), Terrorizing Women: Feminicide in the Americas (Duke University Press 2010) 130.

35 Selmini (n 6) 376.

36 Douglas (n 29) 31.

37 Marc Paantjens, 'EU Policies on Violence against Women. Contested Policy Areas and the Potential of a Governance Approach' in K Deschouwer and M Theo Jans (eds), Politics Beyond the State: Actors and Policies in Complex Institutional Settings (Brussels University Press 2007) 240-41. 
some researchers propose even broader definitions of the term femicide encompassing additional offender's characteristics (a femicide offender is a partner, ex-partner, acquaintance or relative) and specific gender reasons as motives (killing of sex workers by their clients or female victims of human trafficking or obduction, honour killings, dowry-related killings, gender-based infanticide). ${ }^{38}$ The list of femicide elements is inconclusive, and in theory, femicide may involve suicides of violence survivors and femicide offenders as well as killings of third persons (children, friends or relatives) ${ }^{39}$ The variety of definitions proposed in the theoretical discourses on femicide relay on different offender-victim configurations, and departing from this notion, several authors have coined more specific subcategories of femicide. Some use the term intimate femicide, ${ }^{40}$ while others find more suitable the term intimate partner femicide. ${ }^{41}$ For research purposes, Jonson and Sachmann adopted the term femicide-suicide as a multiple killing of family members associated with offender's suicide. ${ }^{42}$ In a growing body of literature on female homicide one can come across the term intimate partner femicide-suicide for the same type of violence. ${ }^{43}$

Defined like this, femicide has surpassed its original meaning and become a quite vague theoretical concept that tries to reconcile diverse elements of homicide scenarios that are characterized by masculine violence. It seems that the notion of femicide carries first and foremost political understanding of the phenomenon under study and the need to emphasize the magnitude of its seriousness and complexity has erased a clear definitional line. Due to the fact that femicide has been seen as a considerable source of premature mortality which has to be placed on the top of political agenda, we are faced with an "umbrella definition" of an "umbrella term". A lack of understanding what the term femicide indeed means is cause of great concern and strong obstacle to transport it into the criminal law framework. Paradoxically, the criminalisation of femicide, domestic violence and related violent phenomenon has been predominantly seen as an effective measure to properly protect women from violence. If we argue that there is no effective system to protect women from abuse without the enactment of concrete criminal offence and at the same time promote broad political understanding of the issue, we are in fact arguing for a paradox. A legal norm to become effective has to be enforceable, and in order to be enforceable, the norm has to be established in accordance with principle of legality. In fact, conciseness and clarity of criminal legal instruments are imperatives imposed by the principle of legality. Accordingly, excessively complex and vague legal norms caused by desire to include as many prohibited behaviours in one criminal offence are repugnant to the very idea of creating a criminal legal norm. Considering the lack of consensus over the meaning of femicide and its complex, multi-causal nature, the term itself has not been imported into the Croatian Criminal Code.

\footnotetext{
38 Sylvia Walby and others, The Concept and Measurement of Violence against Women and Men (Policy Press 2017) 58-64.

39 Selmini (n 6) 376.

$40 \quad$ Stout (n 25) 29-50.

41 McFarlane (n 21) 193-208.

42 Carolyn Johnson and Mark Sachmann, 'Femicide-Suicide: From Myth to Hypothesis and Toward Understanding' (2014) 52(1) Family Court Review 100-13. 


\subsection{THE OFFENCE OF AGGRAVATED MURDER ACCORDING TO THE CROATIAN CRIMINAL CODE}

The Croatian criminal justice system has a long tradition of offering extensive protection to life as a basic constitutional value. A number of offences leading to loss of victim's life are considered the most heinous crimes punishable by serious criminal sanctions. Under Art. 110 of the Criminal Code, whoever murders a person shall face the sentence of imprisonment for a term of at least five years. The upper limit of imprisonment for murder is twenty years at the outmost. ${ }^{44}$ More severe punishment is provided in the Art. 111 . of the same act entitled "aggravated murder". The grammatical analysis of provisions in question reveals that the imprisonment between ten and twenty years as well as long-term imprisonment imposing deprivation of liberty within the penal system between twenty one and forty years have been considered a proper punitive reaction for everyone who commits murder under special, aggravating circumstances. ${ }^{45}$ The circumstances are, according to their criminal substrate, particularly perilous and embodied with different subjective and objective elements providing a basis for further theoretical aggravated murder classification. A person will be held criminally responsible for a death under aggravating circumstances related to three different categories, i.e. offender's modus operandi, motives and victim's status.

Art. 111 provides in part that killing of another in a cruel or perfidious manner constitutes an aggravated murder. ${ }^{46}$ In order to confirm offender's criminal liability, it has to be established that offender acted intentionally and that his / her intent encompassed all the elements of the offence including the manner of killing. According to established court practice, the aggravated murder in a cruel manner shall be a valid qualification if the level of cruelty materialised in victim's pain, suffering and torment goes beyond the "ordinary" level of cruelty specific for murder, as a basic criminal offence. ${ }^{47}$ Therefore, a husband who tortured his wife in a presence of his underage son for a couple of hours and inflicted great violence in the form of multiple, severe, internal and external injuries on her using, among other objects, a wooden table leg, and causing traumatic and hemorrhagic shock that led to death is a perpetrator of aggravated, not simple murder. ${ }^{48}$ The same qualification will be upheld if the murder is accompanied by offender's stealthily, pretentious and perfidious behaviour and abuse of victim's trust. ${ }^{49}$

Moreover, the Art. 111 prohibits individuals from intentionally causing death of a person for profit, ruthless revenge, hatred or other base motives. ${ }^{50}$ While murdering another for profit or for love of gain has been the traditionally recognised aggravating factor in general delict situations out of the sphere of intimate / domestic violence, a recent study has confirmed that crimes committed by men who kill their female partners who demanded divorce or separation 
fall under the ambit of aggravated murder. ${ }^{51}$ The analysis has shown that the termination of relationship as a motive for killing may raise simple to aggravated murder although courts are not unanimous on the issue of whether this fact should be considered as ruthless revenge or some other base motive. ${ }^{52}$ Killings arising from assaults motivated by hatred are aggravated murders under the condition that they are committed on account of a victim's race, colour, religion, national or ethnic origin, language, disability, gender, sexual orientation or gender identity. ${ }^{53}$ In hate killings normative emphasis on motive is more than evident, however, in recent court practice one can find examples in which deciding a case according to offender's hatred of wife's national origin was completely disregarded. No matter the fact that husband attempted to kill his wife first stabbing her with a sharp object in the abdominal area and then strangling her while shouting offensive words and statements that he would not marry her if he knew she was a Serb, the factual substrate was not used to aggravate attempted intentional murder to attempted aggravated murder on the basis of specific heinous motive. ${ }^{54}$ Much lesser ambiguity that clouds the role and value of a motive in aggravated murder cases is associated with murdering a victim in order to commit or cover up another criminal offence. ${ }^{55} \mathrm{~A}$ considerable body of scholarly work focusing on culpability for homicide as a matter of motivation as well as its diverse mitigating and aggravating forms has revealed that killing another as a precondition to complete some other crime or conceal what was already committed usually does not occur in the context of intimate / domestic violence. ${ }^{56}$ Due to its factual nature, the same conclusion is valid for aggravated murder of an official person in relation to his/her performance of official duties. ${ }^{57}$

The last above mentioned type of homicide belongs to a group of aggravated murder based on the victim's status. In 2013, Croatian legislator has broadened the scope of the CC/11 and criminalisation of this particular category of aggravated attacks on life to include additional protection of particularly vulnerable persons and closely related persons. Pursuant to Art. 111. Para. 2, whoever "murders a person who is especially vulnerable due to his/her age, a severe physical or mental disorder or pregnancy" shall be considered an aggravated murderer. The cited provision introduced the institute of particular vulnerability within the boundaries of criminal justice, however, the norm is completely silent as to the meaning of vulnerability. The doctrinal analysis of the provision involved sheds some light offering normative criteria external to the norm through legal reasoning. According to these criteria, a victim is con-

51 Dalida Rittossa and Sandra Juranović, Stručna analiza pravomoćnih kaznenih presuda o nasilju prema ženama 2012-2016 (Pravobraniteljica za ravnopravnost spolova 2020) 90-93.

52 Court ruling K-58/09-127, The County Court in Pula (17 June 2010) (HR); Court ruling K-5/12, The County Court in Split (12 November 2012) (HR); Court ruling 10 K-237/10, The County Court in Zagreb (11 February 2011) (HR); Court ruling 18 K-172/12, The County Court in Zagreb (18 March 2013) (HR); Court ruling I Kž 433/11-9, The Supreme Court of the Republic of Croatia (12 July 2011) (HR); Court ruling I Kž 426/13-4, The Supreme Court of the Republic of Croatia (10 September 2013) (HR); Court ruling I Kž 202/13-6, The Supreme Court of the Republic of Croatia (9 April 2014) (HR).

53 Criminal Code (n 44) art 87 para 21.

54 Court ruling $12 \mathrm{~K}-21 / 13-23$, The County Court in Karlovac (5 February 2014) (HR)

55 Criminal Code (n 44) art 111 para 5.

56 Oliver Mittermayer, 'Presude na Županijskom sudu u Zagrebu za kazneno djelo ubojstva i teškog ubojstva od 1998. do 2002.' (2007) 14(1) Hrvatski ljetopis za kazneno pravo i praksu 77-140; Josip Pavliček, Lana Milivojević Antoliš and Anita Matijević, 'Neke rodne karakteristike počinitelja ubojstava i pokušaja ubojstava u obitelj' (2012) 19(2) Hrvatski ljetopis za kazneno pravo i praksu 917-34. 
sidered to be particularly vulnerable if depends upon others and has a reduced capability to defend against violence. ${ }^{58}$ Nevertheless, the concept itself has been criticised as too vague and fluid having no self-evident meaning, ${ }^{59}$ and subsequently, the decision not to provide additional normative explanation on vulnerability and its gradation might create uncertainty in court practice. Furthermore, according to the constitutional standards and substantive ECtHR court practice, ${ }^{60}$ victims of domestic violence are inherently vulnerable due to patriarchal and discriminatory attitudes, insufficient protective infrastructure and lack of adequate recognition of domestic violence as a widespread, negative phenomenon. Consequently, the question remains what is the precise division line between aggravated murders of particularly vulnerable victims and killings of already abused closely related persons from Art. 111, Para. 3.

Systematic analysis of official state measures to combat all forms of violence against women has revealed that the enactment of legislation is the most common first step. ${ }^{61}$ The Croatian government has implemented the same tactics, and due to the 2011 Criminal Code reform, killing of a closely related person who was already abused by the perpetrator constitutes an aggravated murder. The institute of particular vulnerability and the term "closely related person" both have had no long settled meaning, still, when it comes to the last-mentioned normative concept, very little is left to judicial interpretation. Pursuant to Art. 87, Para. 9, closely related persons are family members, former spouse or cohabitant, former life partner or informal life partner, current or former partner in an intimate relationship, persons having a child together and persons living in a common household. ${ }^{62}$ The term in focus is further generalised by the fact that it also includes family members who cover other closely related persons, more specifically, the spouse or cohabitant, life partner or informal life partner, their children and children of either of them, lineal blood relative, collateral blood relatives up to the third degree of kinship, in-laws up to the second degree as well as adopter and adoptee. ${ }^{63}$ In order to avoid interpretative uncertainties and misaligned conclusions that could appear to arise in case law, the legislator has also defined the terms "cohabitant" and "informal life partner". Under Art. 87, Para. 10, a cohabitant is a person living in a cohabiting union of a more permanent character or for a shorter time if a child is born to cohabiting parents. ${ }^{64}$ Past research has indicated that cohabitation has become an essential part of the family scenery, however, it has also been associated with a risk for intimate / domestic violence. ${ }^{65}$ The said provision reflects this reality providing criminal law reactions to supress abuse and violence in new relationships that exist outside the marital context. The same ratio legis lies behind the definition of informal life

\footnotetext{
58 Cvitanović (n 47) 80.

59 Doris Schroeder and Eugenijus Gefenas, 'Vulnerability: Too Vague and Too Broad?' (2019) 18(2) Cambridge Quarterly of Healthcare Ethics 113-21.

60 Opuz v Turkey App no 33401/02 (ECtHR, 9 June 2009); Eremia v Moldova App no 3564/11 (ECtHR, 28 May 2013); Talpis v Italy App no 41237/14 (ECtHR, 2 March 2017).

61 Manjoo (n 19) 18.

62 Criminal Code (n 44) art 87 para 9.

63 Ibid art 87 para 8.

64 Ibid art 87 para 10.

65 Wendy D Manning, Monica A Longmore and Peggy C Giordano, 'Cohabitation and Intimate Partner Violence during Emerging Adulthood: High Constraints and Low Commitment' (2018) 39(4) Journal of Family Issues 1030; Frédéric Ouellet and others, 'Prédiction de la revictimisation et de la récidive en violence conjugale' (2017) 50(1) Criminologie 312.
} 
partner, a person living in a same-sex partnership of a more lasting character. ${ }^{66}$ The acceptance of formal, criminal legal prohibition of violence in marriage and correlated unions resulting in aggravated murder has undoubtedly moved the state protection narrative from public to private sphere and pushed research on serious violence on multiple fronts even further.

\section{CASE STUDY OF PREVIOUSLY ABUSED VICTIMS}

\subsection{METHODOLOGICAL RESEARCH SETTINGS AND MAIN ETIOLOGICAL ASPECTS}

Recently, the phenomenon of domestic violence has been the subject of numerous scientific and expert discussions in Croatia. This is demonstrated by the fact that, by searching the Croatian Scientific Bibliography database, 160 papers and presentations from scientific and professional conferences were found by entering the keyword "domestic violence". ${ }^{67}$ But despite this, the scientific community has shown much less interest in shedding light on domestic homicide. Twenty papers were written about domestic and intimate partner homicide, and two poster presentations were held. In only one paper, a special etiological variable was the perpetrator's previously delinquent behaviour, viewed in the form of recidivism and classified into non-violent and violent misdemeanours and criminal offences and misdemeanours under Art. 4 of the Law on Protection from Domestic Violence and criminal offence of domestic violence under Art. 215.a CC/97. ${ }^{68}$ Not a single paper addresses the phenomenon of the victim's previous abuse by the perpetrator per se despite numerous studies showing that domestic homicide may be the culmination of a series of violent incidents to which the victim has previously been exposed. As far as the authors are aware, this is the first paper that systematically investigates homicides of closely related persons, whom the perpetrators had previously abused and with whom they had had a close relationship.

Since the circumstance of previous abuse of a closely related person is a qualifying circumstance of aggravated murder under Art. 111, Para. 3 of CC/11, for the purposes of this paper, we researched the case-law of the Supreme Court of the Republic of Croatia. By searching the information system Case Law (Cro. Sudska praksa), we singled out all final judgements in which the perpetrators were found guilty of the criminal offence of aggravated murder in the period from 1 January 2013 to 1 June 2020. In the second research step, first-instance County Court judgements were obtained, based on which the Supreme Court decided on the appeal in the initially singled out judgements. Following such quantitative modelling, the sample was ultimately composed of 18 Supreme Court judgements of conviction and 17 County Court judgements for committing aggravated murder of a previously abused closely related person. The sample also includes judgements which, pursuant to Art. 498. Para. 1, of the Criminal

66 Criminal Code (n 44) art 87 para 11.

67 See Croatian Scientific Bibliography (CROSBI) <https://www.bib.irb.hr> accessed 10 December 2020.

68 Mirjana Kondor-Langer, 'Obiteljska ubojstva: ranije delinkventno ponašanje i tijek kaznenog postupka' (2015) 22(1) Hrvatski ljetopis za kazneno pravo i praksu 153-83; Law on Protection from Domestic Violence (NN 137/2009, 14/2010, 60/2010) (HR) art 4; Criminal Code (n 44) art 215a. 
Procedure Code, amended the final judgement rendered against the same defendant with regards to the sentence, and therefore, in the end, 16 cases of aggravated murder of a previously abused closely related person were analysed. ${ }^{69}$ The primary research goal is to analyse previous abuse circumstances, especially the relationship between the victim and the perpetrator, the duration and frequency of abuse, and the reaction of the environment and competent authorities in cases where they knew about the abuse or when it was reported.

The sample included 16 perpetrators and 18 victims, given that one perpetrator committed a criminal offence to the detriment of multiple victims. Regarding the perpetrators' socio-demographic characteristics, the sample is dominated by middle-aged perpetrators, i.e., those aged 51 to 60 years (six perpetrators), followed by those slightly younger (three perpetrators) or slightly older (three perpetrators). The youngest perpetrator was 36 years old, while the oldest was 75 years old. The fact that all perpetrators in the observed sample are males is particularly indicative. ${ }^{70}$ In terms of educational status, more than half of the perpetrators obtained a secondary education (nine of them), while the data on education are unknown for four perpetrators. Data on perpetrators' employment show that seven of them, or 44\%, had the status of a pensioner at the time of committing the criminal offence, four were unemployed, while employment data were not included in the judgement for five perpetrators. Regarding the number of children (minors and adults included), most perpetrators had two to three children (10 of them, or $62.5 \%$ ), while three had no children.

In terms of criminological and victimological characteristics, the collected data shows that out of a total of 18 victims, as many as 14 of them, or $78 \%$, were the perpetrator's current or former intimate partners (wife or cohabitant). In the remaining four cases, the victims were the perpetrator's father, mother, and two minor children. These data show that all but one of the victims was female, which is in line with previous research conforming that lethal violence in domestic settings is a gender-based violence. ${ }^{71}$ The victims were in most cases killed with a cold weapon (in $44 \%$ of cases it was a knife or an axe), followed by a firearm (33\%) and the use of physical force, and in one case, the perpetrator used gas as a means of committing the criminal offence.

\subsection{PREVIOUS ABUSE OF VICTIMS}

Of a total of 16 perpetrators of aggravated murder of a closely related person, 11 of them, or almost $70 \%$, had previously been convicted of violence to the detriment of the victim whom they subsequently murdered. Of these, two were convicted of committing a criminal offence,

69 Criminal Procedure Act (NN 152/2008, 76/2009, 80/2011, 91/2012, 143/2012, 56/2013, 145/2013, 152/2014, 70/2017, 126/2019, 126/2019) (HR) art 498 para 1.

70 Earlier research also confirms that, in most cases, men are perpetrators of domestic violence. Thus, from 2001 to 2006, the share of male perpetrators of domestic violence was 97\%. Dubravka Rogić-Hadžalić and Jadranka Kos, Nasilje u obitelji 2001-2006 (Državni zavod za statistiku 2008).

71 Previous research also confirms that females are, in most cases, victims of domestic violence. Compare the Report of the Ombudsperson for Gender Equality according to which in 2019, in the Republic of Croatia, out of the total number of victims of criminal acts of violent domestic behaviour and violent behaviour between closely related persons, 3,640 or $78 \%$ of them were women. See Višnja Ljubičić, Izvješće o radu Pravobraniteljice za ravnopravnost spolova za 2019. godinu (Pravobraniteljica za ravnopravnost spolova 2020) 97. 
while the other nine were convicted of a misdemeanour under the Law on Protection from Domestic Violence. $^{72}$

These data deviate significantly from the results of a survey conducted by Kondor-Langer on a sample of 113 cases of homicide and aggravated murder committed in the Republic of Croatia in the period from 2005 to 2010, to the detriment of a family member. According to Kondor-Langer, three perpetrators had been previously convicted of criminal offences with elements of violence to the detriment of the victim, while thirteen perpetrators were convicted of a misdemeanour under Art. 4. of the Law on Protection from Domestic Violence. In other words, $14 \%$ of the total number of perpetrators of homicide and aggravated murder had previously been convicted of violence to the detriment of a victim who was subsequently murdered. A comparison of the data in these two studies shows that it is not excluded that the dark figure for domestic violence is lower today and that victims report violence more frequently.

The courts have established the circumstance of previous abuse of a victim who was subsequently murdered by the perpetrator based on a previous final judgement rendered in criminal or misdemeanour proceedings, but also on the basis of other evidence in cases where such a judgement had not been rendered earlier. Cases in which there was a previous conviction of abuse as well as cases from which it is evident that instances of long-term and severe violence had not been previously processed raise a serious concern about the effectiveness of the justice system and society's sensitivity to domestic violence and call for further in-depth research.

\subsubsection{ABUSE ESTABLISHED ON THE BASIS OF AN EARLIER FINAL JUDGEMENT}

Among the analysed cases, based on their lethal consequences and the number of victims, the case in which the defendant M.S. fired from a Kalashnikov-type automatic rifle at a car with his wife, her partner, and three children (two children of the defendant and the victim and her new partner's son) particularly stands out. The wife tried to escape behind the back of the vehicle, but the defendant fired at her again and murdered her. He then pulled her partner's lifeless body out of the car and fired an unspecified number of bullets into him again. He then released the children, who were left unharmed by a mere stroke of luck. ${ }^{73} \mathrm{M}$. S. is one of the two perpetrators from the analysed sample who had previously been convicted of the criminal offence of neglect and abuse of his minor children (Art. 213, Para. 2 of CC/97). ${ }^{74}$ In the proceedings for the last mentioned offence, it was also established that, in the period of almost five years (from August 2007 to 14 November 2012), he had abused his wife, whom he

72 Current legislation in the Republic of Croatia regulates domestic violence as an independent criminal offence (Criminal Code (n 44) art 179a) and a misdemeanour (Law on Protection from Domestic Violence (n 68) art 10). Furthermore, domestic violence is also prescribed as a qualified form in certain criminal offences (e.g., the criminal offence of serious bodily injury). On the problem of the demarcation of domestic violence as a misdemeanour and a criminal offence, see Marissabell Škorić and Dalida Rittossa, 'Nova kaznena djela nasilja u Kaznenom zakonu' (2015) 22(2) Hrvatski ljetopis za kazneno pravo i praksu 484-500.

73 Court ruling K-29/13, The County Court in Sisak (7 April 2014) (HR); Court ruling I Kž 93-16-5, The Supreme Court of the Republic of Croatia (22 August 2016) (HR).

74 In the second case, eight years before the incriminating event, LJ. Z̆. was sentenced to prison for assaulting his father with a knife and attempting to inflict serious bodily injury. The same perpetrator physically assaulted his father a year before he killed him, for which he was convicted in a Misdemeanour court. In the present case, it was established that the defendant was a person with a permanent personality disorder and that, in the period from March 2006 to July 2014, he was hospitalised fourteen times in a psychiatric institution. Court ruling 9 K-23/15-17, The County Court in Varaždin (12 November 2015) (HR); Court ruling I Kž 41-16-7, The Supreme Court of the Republic of Croatia (8 March 2016) (HR). 
"often told in the presence of their children that she was a whore, a slut, a piece of shit, a cow. He used profanity and spat in her face or in a cooked meal, smashed things around the house. On 14 November 2012, in her apartment, he threatened to kill her, himself, her lover, after which he grabbed her by the neck and started strangling her and let her go only after the child began screaming and ran out of the apartment to search for help. He told his daughters that they were just like their mother, that they were whores, sluts, and cows, and on an unspecified day in late September 2012, he hit his daughter M. in the nose, causing the child to bleed”. It was only after a first-instance judgement was delivered in February 2013 and M. S. was sentenced to one year and six months in prison that he was charged with the criminal offence of threatening, which he committed during November 2012 to the detriment of his wife and her partner. However, it remains unclear why no proceedings were instituted against M. S. for violence against his wife in parallel with the proceedings for neglect and abuse of their children. All the more so because the judgement, based on which he was convicted for a criminal offence under Art. 213, unambiguously states how "the defendant abused his wife for several years and even tried to drown her".

Individual perpetrators were repeatedly reported and convicted of violent misdemeanours against a victim who was later brutally murdered. Thus, the defendant $\check{Z}$. L. was convicted three times of abusing his wife, a mother of seven children, whom he eventually killed by wrapping a noose around her neck which he then tightened and held until her death by strangulation. ${ }^{75}$ Defendant B. A. was also convicted of misdemeanour three times in the period from 2015 to 2017 for verbal and physical abuse of his wife, and he had previously been given a protective measure prohibiting the harassment of his wife. Despite the measure, he remained violent until the incriminating event, when he inflicted more than twenty wounds on the victim with a kitchen knife, resulting in her death. ${ }^{76}$ The defendant M. M. verbally and physically assaulted and threatened his wife over a long period of time, which clearly follows from several judgements and decisions of the Misdemeanour Court, as well as witnesses' testimony. This was also confirmed by their son, who stated in his testimony that "ever since he could remember, the accused had been violent towards his mother, but also towards him". On one occasion, the defendant beat his mother and hit her head against the wall, causing her eardrum to rupture and, on several occasions, he chased her around with a knife. ${ }^{77}$ Even in the case against the defendant M.B., the son testified that his mother's abuse had lasted ever since he could remember. On one occasion, he recalls how his father pushed his mother who fell on the rocks and broke her arm and even beat her with a rifle and a gunstock while she was in a high stage of pregnancy. M. B. had previously been convicted for violence twice before the Misdemeanour Court. ${ }^{78}$

75 Court ruling K-12/2018-15, The County Court in Bjelovar (2 November 2018) (HR); Court ruling I Kž 71-19-4, The Supreme Court of the Republic of Croatia (13 March 2019) (HR).

76 Court ruling 5 K-43/17, The County Court in Zagreb (20 November 2017) (HR); Court ruling I Kž 37-18, The Supreme Court of the Republic of Croatia (7 February 2018) (HR).

77 Court ruling K-2/2016-17, The County Court in Bjelovar (17 March 2016) (HR); Court ruling I Kž 263-16-4, The Supreme Court of the Republic of Croatia (23 March 2017) (HR).

78 In one of these verdicts, the injured party was also found guilty of domestic violence, but the County Court points out that "it follows from the factual description that the deceased actually defended herself from the abuse of the accused. The Court confirms that she never abused or provoked the accused". Court ruling K-17/15, The County Court in Šibenik (24 February 2016) (HR); Court ruling I Kž 246-16-7, The Supreme Court of the Republic of Croatia (12 July 2016) (HR). 
Two months before the disputed event, defendant I. K. was convicted of a misdemeanour for physically abusing the injured party. At that point, the Court imposed on him protective measures to prohibit the approaching and harassment and protective measures of removal from the joint household. Although on that occasion, the defendant was sanctioned for the first time for domestic violence, it was clear from the data contained in the criminal records that he was an extremely dangerous person. Before the incriminating event, I. K. was convicted of as many as 21 criminal offences, of which 16 were with elements of violence (serious bodily injury, robbery, threat, violent behaviour and extortion). I. K. showed extreme aggression and callousness by inflicting on the victim numerous knife injuries from which she died at the scene. ${ }^{79}$ Defendant S. Ž. had only once been previously convicted of violence against his mother, in misdemeanour proceedings, although he had beaten, intimidated and humiliated his mother for several years. Several people had information about this and confirmed in the proceedings that the injured party had bruises on her body and face on a daily basis because her son beat her with his hands and a wooden batten. The accused continuously physically abused his mother as a result of which she often ran away from the house where they lived and sought accommodation and food from neighbours or would sleep in the woods. ${ }^{80}$ In addition to the persistence in committing violence, this perpetrator, like most other perpetrators in the analysed sample, denied the violence. Namely, over $80 \%$ of the defendants, among whom some have been convicted several times, disputed the victim's previous abuse. ${ }^{81}$

The analysed cases revealed that as many as two-thirds of perpetrators had already been convicted of violence to the detriment of a closely related person who was subsequently murdered and that in the majority of cases earlier violence was treated as a misdemeanour. This (once again) confirms the well-known fact that domestic violence shows an ascending trend and that relatively mild forms of violence are followed by much more severe one, which, in a certain number of cases, lead to the victim's death. This also re-actualises the issue of an adequate reaction of the competent authorities, which in most domestic violence cases do not initiate criminal, but rather misdemeanour proceedings. The issue of demarcation of domestic violence as a misdemeanour and a criminal offence is the subject of constant debate in national theory and practice of criminal law, and these examples show that society, despite the double legal regulation of this phenomenon, still fails to achieve its fundamental task - to protect its weaker family members from violence.

\subsubsection{ABUSE ESTABLISHED ON THE BASIS OF OTHER EVIDENCE}

As previously stated, most perpetrators of aggravated murder of a closely related person had previously been convicted of violence against the victim. However, in a number of cases against the perpetrators, no judgements have been pronounced despite years of violent behaviour and reports of violence. Thus, in the proceedings against D. M., the witnesses unanimously testified that the defendant was violent towards the victim and this was also confirmed by

79 Court ruling 6 K-56/2018, The County Court in Zagreb (5 December 2018) (HR); Court ruling I Kž 38-19-9, The Supreme Court of the Republic of Croatia (6 November 2019) (HR).

80 Court ruling K-13/17, The County Court in Zagreb (17 May 2017) (HR); Court ruling I Kž 394-17-4, The Supreme Court of the Republic of Croatia (29 August 2017) (HR). 
the fact that the police intervened in their family home three times in the period of 16 years (1999-2015) due to the accused's violent behaviour towards the injured party. ${ }^{82}$ The day before the incriminating event, the accused was taken to the police station for subjecting the victim to violence where he was detained from $11.40 \mathrm{pm}$ to 9.40 am the following day. After his release, he killed the victim with shots from a rifle that same afternoon. The accused disputed the earlier abuse, referring to the testimonies of certain witnesses (victim's colleagues, neighbours) who stated that they had no knowledge that the accused had previously abused the victim. However, the Court held that this did not mean there was no abuse, as it is "notorious that domestic violence in most cases takes place in a closed family circle, and it is common for such problems to be hidden from the community and work environment, especially in smaller local communities. Therefore, it is logical and acceptable that the mentioned witnesses have no knowledge of these facts, unlike the examined witnesses, family members of the injured party, and her close friend, who certainly knew about the abuse suffered by the injured party in the marital union with the accused". The Court found it undisputed that the accused, as a chronic alcoholic, had verbally, physically and mentally abused his wife for many years. Explaining the judgement, this Court emphasised the complexity of the phenomenon of domestic violence, which accumulates physical, psychological and economic violence, preventing victims from using common property and financial resources, and noted that the most serious criminal offences derived from domestic violence are at a significant increase and occur almost every day. The victims are mostly women who are in a relationship characterised by dependence and subordination to their partners. ${ }^{83}$

In the case against M. Z., it was established that the defendant had previously abused the injured party (for about 20 years before the incriminating event), which is confirmed by the Centre for Social Welfare and the reports of the police department, as well as witnesses' testimonies. The accused insulted her, beat her, slapped her, mistreated her and, on one occasion, wanted to kill her, which is why the police intervened. After that, the injured party continued to live with the children in the same house with the defendant, but separately from him. ${ }^{84}$ According to witnesses' statements, the abuse resumed for two years before the incriminating event. The Court pointed out that, in this case, the fact that the defendant was not convicted for the criminal offence of domestic violence, as the defence had argued, was not relevant because it was evident that the defendant's incriminating behaviour was only a continuation of his previous abuse of the injured party. The second-instance court also found that the defence's allegation that no abuse could be established due to the lack of material evidence did not call into question the credibility of witnesses' testimony since the police and the Centre for Social Welfare reported earlier abuse. However, the question that remains unanswered in this case is how it is possible there was no crime report against M. Z. when the Court showed full trust in witnesses' testimony that the defendant wanted to murder the victim 20 years ago, which was the reason for the police intervention. ${ }^{85}$

82 In 2013, the victim went to the counselling centre of a women's group to find out about the possibilities of divorce due to psychological and economic violence by the accused, but in the end, she gave up on the divorce option due to ownership relations.

83 Court ruling 12 K-6/2018-33, The County Court in Karlovac (26 March 2019) (HR); Court ruling I Kž 306-19-8, The Supreme Court of the Republic of Croatia (5 December 2019) (HR).

84 The defendant stayed at the house occasionally since he was employed in Germany.

85 During the proceedings, it was found that tempore criminis the defendant was mentally incompetent. Court ruling 18 K-8/19-59, The County Court in Zadar (12 June 2019) (HR); Court ruling I Kž 577-19-4, The Supreme Court of the Republic of Croatia (6 November 2019) (HR). 
In a number of cases against the perpetrator not only were no criminal or misdemeanour proceedings conducted, but previous violence was nowhere reported or recorded. ${ }^{86}$ One has to wonder how it is possible that no charges have been filed against the perpetrator for domestic violence, although in some cases it was extremely brutal and lasted for many years. Particularly tragic is the case of an injured party who suffered frequent psychological and physical abuse throughout her marriage, for more than 30 years. The defendant beat her with his hands and feet, pulled her by the hair and hit her head against the concrete, which made her run away often with their children to the neighbours. One of the consequences of this violence was a miscarriage, as the defendant beat her while she was pregnant. The Court noted that the victim did not want to leave the marital community due to traditional upbringing and the fact that they lived in a small, closed, rural environment where she did not have broader social support. This is confirmed by the fact that none of the family members and neighbours reported violence that undoubtedly occurred frequently over a long period of time. ${ }^{87}$ In the case of Ž. Š., the Court unequivocally found that the accused had frequently insulted and mentally and physically abused his wife throughout the years of their marriage, which made her often spend the night with her children in the homes of her relatives. The daughters stated that their father was violent towards their mother and when they tried to protect her, he directed his violence at them as well. Ever since they could remember, they have lived in constant fear due to the accused's physical and mental harassment, who repeatedly threatened to kill and slaughter them and, on one occasion, almost strangled one of his daughters. The defendant denied their allegations and claimed that "if he had indeed abused the injured party in this way during her 39 years of marriage, she would certainly have sought protection from relevant state institutions such as the police, social welfare centre, doctors, psychologists, etc". The Supreme Court assessed such defence as unsound and pointed out that "it is common knowledge that victims of domestic violence do not report abuse at all and suffer violence due to economic dependence or other reasons in many cases, which is why domestic perpetrators often remain outside the reach of law enforcement" ${ }^{88}$ In the next case as well, the Court determined the qualifying circumstance of the previous abuse on the basis of the testimony of the injured party and witnesses and the relevant medical documentation. The injured party clearly and convincingly testified about how the defendant would literally beat her to death, which made her unrecognisable and prompted to take refuge with her friends. However, he would find her and repeatedly broke into the apartments where she took refuge. Her testimony was confirmed by witnesses to whom the victim came on a number of occasions in bruises, with haematomas on her face, bloody, and without teeth. Medical documentation further supports the injured party's testimony about the previous abuse. Namely, due to the defendant's injuries inflicted on her, the injured party repeatedly sought medical help. Therefore, the medical documentation shows that during their two and a half year-long cohabitation, she suffered various injuries, from a series of haematomas, bruises and scratches all over her body, including the head and neck, to the fractured nasal bone. Given the abovementioned, it is not clear how no charges

86 Court ruling 2 K-22/17-71, The County Court in Varaždin (25 May 2018) (HR); Court ruling I Kž 421-18-4, The Supreme Court of the Republic of Croatia (10 October 2018) (HR); Court ruling 2 K-13/18-77, The County Court in Varaždin (18 December 2018) (HR); Court ruling I Kž 114-19-4, The Supreme Court of the Republic of Croatia (2 April 2019) (HR).

87 Court ruling 12 K-11/15-135, The County Court in Karlovac (28 October 2016) (HR); Court ruling III Kž 2-17-4, The Supreme Court of the Republic of Croatia (31 July 2017) (HR).

88 Court ruling K-7/2018-33, The County Court in Osijek (July 17, 2018) (HR); Court ruling I Kž 377-19-8, The Supreme Court of the Republic of Croatia (16 October 2019) (HR). 
were filed against the defendant for violence against the injured party, but only misdemeanour charges for disturbing the public order and peace. ${ }^{89}$

\section{CONCLUSION}

In last two decades Croatian criminal justice system has been marked by a clear trace of normative activism. Under the dictate of complex criminal legal reform, the new normative solutions were introduced, inter alia, in order to supress domestic violence, offer better protection to their victims and raise public awareness in terms of general prevention. The legislator has made a tactical move and widened the net of offences and misdemeanours accepting the international normative standards for eliminating violence against women. The criminal offence of aggravated murder of a previously abused closely related person referred to Art. 111, Para. 3 was introduced in the catalogue of CC/11 incriminations in order to fulfil a state's obligation arising from the normative framework of the Council of Europe Convention on Preventing and Combating Violence against Women and Domestic Violence. The acceptance of formal, criminal legal prohibition of repeating violence in family settings that results in aggravated murder has, on the one side, undoubtedly pushed the state's protection against violence to private sphere even further, and on the other, maintained normative clarity embodied within the principle of criminal legality. The analysis has shown that broad political understanding that lies behind the notion of femicide is contrary to the demand that criminal offences have to be foreseeable (nullum crimen sine lege certa). Although a wide consensus exists that the model of the most heinous crimes against life is in accordance with the conceptual and theoretical framework of criminal law, the question remains whether it is enforceable in practice. The enactment of legislation is the most common first step to supress lethal violence in domestic settings, however, it is an imperative to reinforce it with additional repressive and preventive measures.

The analysed judgements show that $70 \%$ of all offenders are recidivist violent offenders who had previously abused and attacked the victims whom they subsequently murdered. The majority of them (9 of 11) were charged and convicted of a manslaughter crime of domestic violence while the other two were declared guilty of a violent criminal offence by an effective court judgement. Moreover, a significant shift can be noticed in the recognition of the phenomenon of domestic violence and the different modalities of its commission. Given that domestic violence is a social ill that often remains invisible and hidden for a long time, the courts did not accept the defence of perpetrators who denied previous abuse, citing the fact that no charges of domestic violence had been filed against them before. In the absence of effective court judgments, the circumstances of previous abuse were established by the courts on the basis of other evidence. It is particularly important that the courts have recognised economic violence as one of domestic violence modalities. The inability to use the common property and financial resources further places the victim in a subordinate and dependant position causing an obstacle for independent life. Therefore, the economic violence in abusive relationships

89 Court ruling 3 K-20/2017-126, The County Court in Karlovac (29 November 2018) (HR); Court ruling I Kž 103-19-8, The Supreme Court of the Republic of Croatia (16 April 2019) (HR). 
should be given additional attention, and appropriate measures should be taken to ensure that victims are adequately supported to exercise their property rights. The analysed judgements also show that there are still cases of domestic violence that have remained tacitly tolerated and marginalised for years and without an adequate response, both from the environment in which they occur and from the competent state bodies. The fact that the violence was not reported, even in cases where it lasted for many years and the environment was aware of it, shows that the concept that domestic violence is exclusively a private affair unfortunately still exists. The case analysis shows that consequences of not reporting domestic violence or the competent authorities' inadequate reaction to reported violence are tragic and irrevocable. Therefore, further efforts should be made to sensitise the public and to provide continuous education and specialisation for professionals working with domestic violence victims.

In recent months the COVID-19 pandemic has additionally emphasized the importance of complete functional system for protection of domestic violence victims. Many experts warn that during the COVID-19 crisis, the risk of family abuse has escalated. The mandatory lockdown, as a measure to prevent the spread of COVID-19, has trapped victims of domestic violence in their homes with abusers for 24 hours a day, isolating them from friends, family and services that support their safety and well-being. Social implications of COVID-19 crisis are a considerable social stressor and lockdown cohabitation has exposed victims to higher risk of abuse behind closed family home doors. In such circumstances, the amount and quality of involvement from those responsible for applying and enforcing the law has additional significance.

\section{BIBLIOGRAPHY}

1. Calanchi A, 'Crime, Crime Fiction, and the Construction of Public Feeling through the Media in Italy' (2014) 32(2) Italian Americana 172

2. Campbell J and Runyan C, 'Femicide: Guest Editors Introduction' (1998) 2(4) Homicide Studies 347

3. Corry J, A Satirical View of London (4th edn, Dutton and Agg 1809)

4. Cvitanović L, and others, Kazneno pravo: Posebni dio (Pravni fakultet Sveučilišta u Zagrebu 2018)

5. Dick C, 'A Tale of Two Cultures: Intimate Femicide, Cultural Defences, and the Law of Provocation' (2011) 23(2) Canadian Journal of Women and the Law 519

6. Dillbeck MC and Cavanaugh KL, 'Societal Violence and Collective Consciousness: Reduction of U.S. Homicide and Urban Violent Crime Rates' (2016) 6(2) SAGE Open <https://doi.org/10.1177/ 2158244016637891> accessed 4 October 2021

7. Douglas CA, 'Femicide in Global Perspective' (2001) 31(11) Off Our Backs 31

8. Grant I, 'Intimate Famicide: A Study of Sentencing Trends for Men Who Kill Their Intimate Partner's' (2010) 47(3) Alberta Law Review 779

9. Johnson C and Sachmann M, 'Femicide-Suicide: From Myth to Hypothesis and Toward Understanding' (2014) 52(1) Family Court Review 100

10. Kennedy H, 'Not Enough Has Changed' [2006] 43 Socialist Lawyer 18

11. Kondor-Langer M, 'Obiteljska ubojstva: ranije delinkventno ponašanje i tijek kaznenog postupka' (2015) 22(1) Hrvatski ljetopis za kazneno pravo i praksu 153 
12. Koziol-McLain J and others, 'Risk Factors for Femicide-Suicide in Abusive Relationships: Results form a Multisite Case Control Study' (2006) 21(1) Violence and Victims 3

13. Langhinrichsen-Rohling J, McCullars A and Misra TA, 'Motivations for Men and Women's Intimate Partner Violence Perpetration: A Comprehensive Review' (2012) 3(4) Partner Abuse 429

14. Ljubičić V, Izvješće o radu Pravobraniteljice za ravnopravnost spolova za 2019. godinu (Pravobraniteljica za ravnopravnost spolova 2020)

15. Loinaz I, Marzabal I and Andrés-Pueyo A, 'Risk Factors of Female Intimate Partner and Non-Intimate Partner Homicides' (2018) 10(2) The European Journal of Psychology Applied to Legal Context 49

16. Manjoo R, 'The Continuum of Violence against Women and the Challenges of Effective Redress' (2012) 1(1) International Human Rights Law Review 1

17. Manning WD, Longmore MA and Giordano PC, 'Cohabitation and Intimate Partner Violence during Emerging Adulthood: High Constraints and Low Commitment' (2018) 39(4) Journal of Family Issues 1030

18. McFarlane J, Campbell JC and Watson K, 'The Use of the Justice System Prior to Intimate Partner Femicide' (2001) 26(2) Criminal Justice Review 193

19. Mittermayer O, 'Presude na Županijskom sudu u Zagrebu za kazneno djelo ubojstva i teškog ubojstva od 1998. do 2002.' (2007) 14(1) Hrvatski ljetopis za kazneno pravo i praksu 77

20. North DC, Wallis JJ and Weingast BR, Violence and Social Orders: A Conceptual Framework for Interpreting Recorded Human History (rep edn, Cambridge University Press 2012)

21. Ouellet $\mathrm{F}$ and others, 'Prédiction de la revictimisation et de la récidive en violence conjugale' (2017) 50(1) Criminologie 311

22. Paantjens M, 'EU Policies on Violence against Women. Contested Policy Areas and the Potential of a Governance Approach' in K Deschouwer and M Theo Jans (eds), Politics Beyond the State: Actors and Policies in Complex Institutional Settings (Brussels University Press 2007) 238

23. Parmigiani G, 'Femminicidio and the Emergence of a "community of sense" in Contemporary Italy' (2018) 23(1) Modern Italy 19

24. Pavliček J, Milivojević Antoliš L and Matijević A, 'Neke rodne karakteristike počinitelja ubojstava i pokušaja ubojstava u obitelji' (2012) 19(2) Hrvatski ljetopis za kazneno pravo i praksu 917

25. Rittossa D and Juranović S, Stručna analiza pravomoćnih kaznenih presuda o nasilju prema ženama 2012-2016 (Pravobraniteljica za ravnopravnost spolova 2020)

26. Rogić-Hadžalić D and Kos J, Nasilje u obitelji 2001-2006 (Državni zavod za statistiku 2008)

27. Rudolph $\mathrm{M}$ and Starke $\mathrm{P}$, 'How does the welfare state reduce crime? The effect of program characteristics and decommodification across 18 OECD-countries' (2020) 68 Journal of Criminal Justice 101684 <https://doi.org/10.1016/j.jcrimjus.2020.101684> accessed 4 October 2021

28. Russell DEH and Harmes RA, Femicide in Global Perspective (Teachers College Press 2001)

29. Saunders DG and Browne A, 'Intimate Partner Homicide' in RT Ammerman and M Hersen (eds), Case Studies in Family Violence (Kluwer Academic Publishers 2000) 415

30. Savigny H, Cultural Sexism: The Politics of Feminist Rage in the \#metoo Era (Bristol University Press 2020)

31. Schroeder D and Gefenas E, 'Vulnerability: Too Vague and Too Broad?' (2019) 18(2) Cambridge Quarterly of Healthcare Ethics 113

32. Selmini R and McElrath S, 'Violent Female Victimization Trends across Europe, Canada, and the United States' (2014) 43 Crime and Justice 367 
33. Shifman P, Madlala-Routledge $\mathrm{N}$ and Smith V, 'Women in Parliament Caucus for Action to End Violence' (1997) 13(36) Agenda: Empowering Women for Gender Equity 23

34. Škorić M and Rittossa D, 'Nova kaznena djela nasilja u Kaznenom zakonu' (2015) 22(2) Hrvatski ljetopis za kazneno pravo i praksu 483

35. Stöckl H and others, 'The Global Prevalence of Intimate Partner Homicide: A Systematic Review' (2013) 382(9895) The Lancet 859

36. Stout K, 'Intimate Femicide: An Ecological Analysis' (1992) 19(3) Journal of Sociology and Social Welfare 29

37. Tonry M, 'Why Crime Rates Are Falling throughout the Western World' (2014) 43 Crime and Justice 1

38. True J, 'Continuums of Violence and Peace: A Feminist Perspective' (2020) 34(1) Ethics \& International Affairs 85

39. Trujillo HM, 'Femicide and Sexual Violence in Guatemala' in RL Fregoso and AC Bejarano (eds), Terrorizing Women: Feminicide in the Americas (Duke University Press 2010) 127

40. United Nations Office on Drugs and Crime, Global Study on Homicide 2019: Executive summary (United Nations 2019) <https://www.unodc.org/documents/data-and-analysis/gsh/Booklet1.pdf> accessed 4 October 2021

41. Walby $S$ and others, The Concept and Measurement of Violence against Women and Men (Policy Press 2017)

42. Wharton JJS and Lely JM, Wharton's Law-Lexicon: Forming an Epitome of the Law of England; And Containing Full Explanations of the Technical Terms and Phrases Thereof, Both Ancient and Modern. Including the Various Legal Terms Used in Commercial Business; Together with a Translation of Latin Law Maxims, and Selected Titles from the Civil, Scotch, and Indian Law (7th edn, Soule and Bugbee 1883)

43. Wharton JJS, The Law Lexicon or Dictionary of Jurisprudence: Explaining All the Technical Words and Phrases Employed in the Several Departments of English Law; Including Also the Various Legal Terms Used in Commercial Transactions; Together with an Explanatory as Well as Literal Translation of the Latin Maxims Contained in the Writings of the Ancient and Modern Commentators (Spettigue and Farrance1848)

44. Wykes M and Welsh K, Violence, Gender and Justice (Sage Publications 2009)

45. Zara G and others, 'The Medicolegal, Psycho-Criminological, and Epidemiological Reality of Intimate Partner and Non-Intimate Partner Femicide in North-West Italy: Looking Backwards to See Forwards' (2019) 133(4) International Journal of Legal Medicine 1295

\section{REGULATIONS AND DOCUMENTS}

1. Criminal Code (NN 110/1997, 27/1998, 50/2000, 129/2000, 84/2005, 51/2001, 111/2003, 190/2003, 105/2004, 71/2006, 110/2007, 152/2008, 57/2011, 77/2011) (HR)

2. Criminal Code (NN 125/2011, 144/2012, 56/2015, 61/2015, 101/2017, 118/2018, 126/2019, 84/2021) (HR)

3. Criminal Procedure Act (NN 152/2008, 76/2009, 80/2011, 91/2012, 143/2012, 56/2013, 145/2013, 152/2014, 70/2017, 126/2019, 126/2019) (HR)

4. In-depth study on all forms of violence against women: Report of the Secretary-General (United Nations General Assembly, Document A/61/122/Add.1, 6 July 2006) 
5. Law on Protection from Domestic Violence (NN 137/2009, 14/2010, 60/2010) (HR)

6. Law on Protection from Domestic Violence (NN 70/2017, 126/2019, 84/2021) (HR)

7. United Nations General Assembly, Transforming our world: the 2030 Agenda for Sustainable Development (Resolution A/RES/70/1, 25 September 2015)

\section{JUDGMENTS AND OTHER DECISIONS}

1. Court ruling $10 \mathrm{~K}-237 / 10$, The County Court in Zagreb (11 February 2011) (HR)

2. Court ruling $11 \mathrm{~K}-12 / 15$, The County Court in Zadar (23 November 2015) (HR)

3. Court ruling $12 \mathrm{~K}-11 / 15-135$, The County Court in Karlovac (28 October 2016) (HR)

4. Court ruling 12 K-21/13-23, The County Court in Karlovac (5 February 2014) (HR)

5. Court ruling 12 K-6/2018-33, The County Court in Karlovac (26 March 2019) (HR)

6. Court ruling $18 \mathrm{~K}-172 / 12$, The County Court in Zagreb (18 March 2013) (HR)

7. Court ruling 18 K-8/19-59, The County Court in Zadar (12 June 2019) (HR)

8. Court ruling 2 K-13/18-77, The County Court in Varaždin (18 December 2018) (HR)

9. Court ruling 2 K-22/17-71, The County Court in Varaždin (25 May 2018) (HR)

10. Court ruling 3 K-20/2017-126, The County Court in Karlovac (29 November 2018) (HR)

11. Court ruling $5 \mathrm{~K}-43 / 17$, The County Court in Zagreb (20 November 2017) (HR)

12. Court ruling 5 K-78/14, The County Court in Zagreb (1 June 2015) (HR)

13. Court ruling 6 K-56/2018, The County Court in Zagreb (5 December 2018) (HR)

14. Court ruling 9 K-23/15-17, The County Court in Varaždin (12 November 2015) (HR)

15. Court ruling I Kž 103-19-8, The Supreme Court of the Republic of Croatia (16 April 2019) (HR)

16. Court ruling I Kž 114-19-4, The Supreme Court of the Republic of Croatia (2 April 2019) (HR)

17. Court ruling I Kž 202/13-6, The Supreme Court of the Republic of Croatia (9 April 2014) (HR)

18. Court ruling I Kž 208-16-7, The Supreme Court of the Republic of Croatia (30 May 2016) (HR)

19. Court ruling I Kž 246-16-7, The Supreme Court of the Republic of Croatia (12 July 2016) (HR)

20. Court ruling I Kž 263-16-4, The Supreme Court of the Republic of Croatia (23 March 2017) (HR)

21. Court ruling I Kž 306-19-8, The Supreme Court of the Republic of Croatia (5 December 2019) (HR)

22. Court ruling I Kž 37-18, The Supreme Court of the Republic of Croatia (7 February 2018) (HR)

23. Court ruling I Kž 377-19-8, The Supreme Court of the Republic of Croatia (16 October 2019) (HR)

24. Court ruling I Kž 38-19-9, The Supreme Court of the Republic of Croatia (6 November 2019) (HR)

25. Court ruling I Kž 394-17-4, The Supreme Court of the Republic of Croatia (29 August 2017) (HR)

26. Court ruling I Kž 41-16-7, The Supreme Court of the Republic of Croatia (8 March 2016) (HR)

27. Court ruling I Kž 421-18-4, The Supreme Court of the Republic of Croatia (10 October 2018) (HR)

28. Court ruling I Kž 426/13-4, The Supreme Court of the Republic of Croatia (10 September 2013) (HR)

29. Court ruling I Kž 433/11-9, The Supreme Court of the Republic of Croatia (12 July 2011) (HR)

30. Court ruling I Kž 577-19-4, The Supreme Court of the Republic of Croatia (6 November 2019) (HR)

31. Court ruling I Kž 71-19-4, The Supreme Court of the Republic of Croatia (13 March 2019) (HR)

32. Court ruling I Kž 93-16-5, The Supreme Court of the Republic of Croatia (22 August 2016) (HR) 
33. Court ruling III Kž 2-17-4, The Supreme Court of the Republic of Croatia (31 July 2017) (HR)

34. Court ruling K-12/2018-15, The County Court in Bjelovar (2 November 2018) (HR)

35. Court ruling K-13/17, The County Court in Zagreb (17 May 2017) (HR)

36. Court ruling K-17/15, The County Court in Šibenik (24 February 2016) (HR)

37. Court ruling K-2/2016-17, The County Court in Bjelovar (17 March 2016) (HR)

38. Court ruling K-29/13, The County Court in Sisak (7 April 2014) (HR)

39. Court ruling K-5/12, The County Court in Split (12 November 2012) (HR)

40. Court ruling K-58/09-127, The County Court in Pula (17 June 2010) (HR)

41. Court ruling K-7/2018-33, The County Court in Osijek (July 17, 2018) (HR)

42. Court ruling KZM-10/14, The County Court in Zagreb (2 March 2015) (HR)

43. Eremia $v$ Moldova App no 3564/11 (ECtHR, 28 May 2013)

44. Opuz v Turkey App no 33401/02 (ECtHR, 9 June 2009)

45. Talpis v Italy App no 41237/14 (ECtHR, 2 March 2017) 


\section{NAPUŠTENE I ZABORAVLJENE? NASILNA SMRT RANIJE ZLOSTAVLJANIH ŽENA U HRVATSKOJ}

\section{Sažetak}

Kako bi se jasno sagledali različiti aspekti nasilnih usmrćenja žena koje su prethodno bile zlostavljane, rad je sadržajno podijeljen u dva dijela.

U prvom dijelu rada dan je sažet prikaz rezultata najnovijih fenomenoloških istraživanja o nasilju koje rezultira lišenjem života uz objašnjenje zašto u takva istraživanja treba uključiti parametre vezane uz rodne razlike. Mnogobrojna istraživanja potvrdila su da su žene većinom žrtve ubojstava u obiteljskom krugu i da smrtna posljedica predstavlja eskalaciju ranije pretrpljenog nasilja. Kako bi se pridonijelo daljnjem rasvjetljavanju obiteljskih ubojstava žena, u radu su analizirane različite definicije takvih ubojstava i naznačena jasna crta razgraničenja između pojma femicid i teškog ubojstva bliske osobe koju je počinitelj već ranije zlostavljao.

U drugom dijelu rada autorice analiziraju presude Vrhovnog suda Republike Hrvatske u predmetima u kojima su počinitelji pravomoćno osuđeni za kazneno djelo teškog ubojstva bliske osobe koju su već ranije zlostavljali (članak 111. točka 3. Kaznenog zakona) u razdoblju od 1. siječnja 2013. do 1. lipnja 2020. godine. Istraživanje je prvenstveno bilo usmjereno na okolnost ranijeg zlostavljanja, posebice na odnos između žrtve i počinitelja, trajanje i učestalost zlostavljanja te reakciju okoline i nadležnih tijela kada su imali saznanja o zlostavljanju ili im je ono bilo prijavljeno.

Ključne riječi: $\quad$ femicid, teško ubojstvo, ranije zlostavljanje, bliska osoba, obiteljsko nasilje, sudska praksa

\section{(c) (1) (8)}

This work is licensed under a Creative Commons

Attribution-NonCommercial 4.0 International License.

* Dr. sc. Dalida Rittossa, izvanredna profesorica Pravnog fakulteta Sveučilišta u Rijeci, Hahlić 6, 51000 Rijeka. E-adresa: dalida. rittossa@pravri.uniri.hr. ORCID: https://orcid.org/0000-0002-1452-0838.

** Dr. sc. Marissabell Škorić, redovita profesorica Pravnog fakulteta Sveučilišta u Rijeci, Hahlić 6, 51000 Rijeka. E-adresa: skoric@ pravri.hr. ORCID: https://orcid.org/0000-0003-0627-3651. 